\title{
Trends in the development of the banking system in the Far North of the Russian Federation
}

\author{
Lyudmila Pushkareva ${ }^{1, *}$ and Mikhail Pushkarev ${ }^{2}$ \\ ${ }^{1}$ North-West Institute of management of the Russian Presidential Academy of National Economy and \\ Public Administration (NWIM RANEPA), Saint-Petersburg \\ ${ }^{2}$ Saint-Petersburg State Institute of Technology, 190013, 26 Moskovsky prospect, St. Petersburg, \\ Russia
}

\begin{abstract}
In this paper, the author summarizes the main problems that have to be solved by regional commercial banks and, in particular, banks in the Far North and equivalent territories in the current political situation and conditions of economic sanctions. The country's banking system is not adequate to the needs of the national economy and is unable to provide resources for the country's modernization. The ability of banks to finance the needs of the real sector is significantly constrained by the lack of longterm and cheap financial resources from the banks themselves.
\end{abstract}

\section{Introduction}

In recent years, the Russian economy has entered a period of recession, which is caused by both external and internal factors. The most effective way to solve the current problems is through structural reforms and economic diversification. Banks play a key role in largescale reforms. It is through them that the state policy is implemented to regulate the national economy and achieve the goals of economic and social development.

The Russian banking system, like the entire economy, is unevenly developed. The heterogeneity of the economic space of Russia with highly differentiated living conditions of the population and production in various territories has a significant impact on the structure and efficiency of the economy, its banking sector, and requires scientific research.

The territories of the Russian Federation in the Far North play a key role in the national economy, in ensuring the security and geopolitical interests of Russia. These territories are characterized by harsh natural and climatic conditions, which lead to increased costs of production and live support of the population.

\section{Materials and methods}

This work was carried out on the personal initiative of the authors using the methods of monographic description, comparative analysis, materials of scientific and practical

\footnotetext{
*Corresponding author: plv1412@mail.ru
} 
conferences, scientific seminars and round tables, where the above issues were discussed, literature sources and official publications on the problem in the open access.

\section{Results and discussion}

The regions of the North include, in whole or in part, the territories of 6 republics, 3 territories ("krai"), 10 regions and 8 autonomous okrugs. More than 11.7 million people live here, of which more than 200 thousand people are representatives of 30 indigenous small-numbered peoples of the North [1]. Only 6 out of 24 northern regions are nonsubsidized, in the rest - industry, infrastructure, and financial intermediation are insufficiently developed.

High production costs without appropriate compensation mechanisms lead to a difficult financial situation of operating enterprises and, as a consequence, a low quality of life of the population [2].

2019 turned out to be quite unique in the degree of concentration of various circumstances that will affect economic activity and the banking sector in Russia in the coming years. The most important of them are:

The geopolitical situation that caused international sanctions against Russia.

Awareness of the need to restructure the country's economy and search for ways to implement it.

One of the serious threats to the country's economy (and everyone understands this) is that Russian banks don't have sufficient resources acceptable for borrowers to support economic development processes at the stage of business activity returning to positive growth dynamics.

So, today the key problem is: the country's banking system is not adequate to the needs of the national economy and is unable to provide resources for the country's modernization. The ability of banks to finance the needs of the real sector is significantly constrained by the lack of long-term and cheap financial resources from the banks themselves. Banks have to focus on loans from the Central Bank of the Russian Federation and deposits of legal entities as a source of funds for the short term, and deposits of individuals - for the medium term. As a result, the majority of commercial banks have to form resources at the expense of liabilities of lesser maturity and potential risks of liquidity loss.

What problems do we observe when forming the resource base of banks from sources of the domestic market?

Only large banks can count on support within the framework of the Government's AntiCrisis Plan to ensure sustainable economic development and social stability [3].

They have the opportunity to receive funds to increase capitalization under the government program using the funds of the National Wealth Fund through the Deposit Insurance Agency in the form of a subordinated loan. Within the framework of this program for additional capitalization, a list of 27 large systemically important banks (with a capital of more than 25 billion rubles) was formed. These are federal-level banks, they meet the requirements established by the state and the Deposit Insurance Agency (DIA) [4] and will receive 830 billion rubles through federal loan bonds (FLB). However, the beneficiaries have a number of conditions that they must fulfill on their part (not all selected banks may like this and will agree to such support).

a mandatory monthly increase in lending to enterprises of priority sectors of the economy by at least $1 \%$;

banks should increase the total volume of mortgage lending, the volume of lending to small and medium-sized businesses;

for each ruble of state aid, banks will have to invest 0.5 rubles in capital from own funds or funds of shareholders; 
for three years, beneficiaries will not be able to increase the remuneration of management and the size of the salary fund for other employees;

banks will be required to allocate no more than $25 \%$ of their profits for dividends;

DIA acquires the right to control the process of their additional capitalization.

In addition, it is planned to allocate 9 billion rubles to regional banks through the FLB mechanism [5]. However, only regional banks, whose equity capital exceeds 5 billion rubles, can enter into the additional capitalization program. In addition, capital aid is provided for only one bank from the region with the largest capital.

It should be noted that the program not only provides capital, but also imposes on the regionals the same restrictions as on federal banks - on limiting the size of the wage fund, increasing lending to the real sector, additional capitalization by shareholders of at least $50 \%$ of the state support.

The capitalization of regional banks is supposed to be increased through the Rossiysky Kapital JSCB by increasing its own funds (capital) due to issuing preferred shares and paying them by the Deposit Insurance Agency with federal loan bonds (FLB) with their subsequent placement in subordinated obligations of regional banks. On the one hand, only 8 regional banks fall under this program [6], which is clearly not enough to strengthen the regional banking sector, and on the other hand, the question remains whether these banks will be able to use this opportunity. The restrictions imposed by the program may turn out to be unbearable for individual banks and, in particular, it concerns participation in the capitalization of shareholders.

By the end of 2019, the share of state-owned banks' assets in total assets, according to ADB, will approach $60 \%$ [7].

Expensive funding is the funds of the Central Bank of the Russian Federation and deposits of the population.

Low ability to maneuver due to the prevalence of interest income.

On average, the ratio of non-interest income to interest income is $30 \%$ to $70 \%$ and has remained unchanged for many years.

Banking activities can be conditionally divided into two large blocks: financing and providing settlements. Providing settlements allows clients to:

conduct day-to-day operational activities;

carry out settlements with their counterparties by sending and receiving payments in any form, using any instruments, via any communication channels.

As a type of operating activity, this area has existed as long as there are banks. But it began to be viewed as a business relatively recently. This is the so-called transactional business.

During crisis periods, credit risks increase. The share of unprofitable credit institutions continues to grow. Interest rates on already issued loans remain low, new money is more expensive, and the issuance of new loans is decreasing. According to the ARB, from 2014 to March 2019, the number of unprofitable credit institutions increased from $8 \%$ to $30 \%$ [8].

With regard to the country's banking system, the following trends can be predicted in the near future:

Focus on state-controlled banks, whose share in the financial market has a clearly pronounced upward trend, which is caused by the support from the authorities. In particular, this is facilitated by the implementation of the government's anti-crisis plan. Although, it should be remembered that the market economy is based, as we understand it, on the universal principles of competition.

Stable demand for loans from those corporate clients who are forced to take loans (especially for replenishment of working capital) at any rates, but they will reduce the volume of attracted loans and their terms. 
Potentially high demand for loans will be shown by those companies that make or plan to make domestic investments - especially large and medium-sized businesses.

The growth of overdue debts of both companies and individuals will continue, which will entail the need for banks to build up significant reserves and reduce profits, as well as reduce the terms of new loans. level.

The dynamics of the inflow of individuals' deposits to banks will remain at the inflation

Table 1. Placement of operating credit institutions (CIs) by federal district.

\begin{tabular}{|c|c|c|c|c|c|c|c|c|}
\hline \multirow[t]{2}{*}{ Name } & \multicolumn{2}{|c|}{01.01 .2017} & \multicolumn{2}{|c|}{01.01 .2018} & \multicolumn{2}{|c|}{01.01 .2019} & \multicolumn{2}{|c|}{01.04 .2019} \\
\hline & \begin{tabular}{|c|} 
Number \\
of CIs, \\
units
\end{tabular} & $\begin{array}{l}\% \% \text { to the } \\
\text { total }\end{array}$ & $\begin{array}{c}\text { Number } \\
\text { of CIs, } \\
\text { units }\end{array}$ & $\begin{array}{l}\text { in } \% \text { to the } \\
\text { total }\end{array}$ & $\begin{array}{c}\text { Number of } \\
\text { CIs, units }\end{array}$ & $\begin{array}{c}\text { in } \% \text { to the } \\
\text { total }\end{array}$ & $\begin{array}{c}\text { Number of } \\
\text { CIs, units }\end{array}$ & $\begin{array}{c}\text { in } \% \text { to the } \\
\text { total }\end{array}$ \\
\hline $\begin{array}{l}\text { Central Federal } \\
\text { District }\end{array}$ & 564 & 59.0 & 547 & 59.3 & 504 & 60.4 & 501 & 60.8 \\
\hline $\begin{array}{l}\text { including Moscow } \\
\text { and Moscow } \\
\text { region }\end{array}$ & 506 & 52.9 & 498 & 54.0 & 459 & 55.0 & 456 & 55.3 \\
\hline $\begin{array}{l}\text { Northwestern } \\
\text { Federal District }\end{array}$ & 70 & 7.3 & 70 & 7.6 & 64 & 7.7 & 64 & 7.8 \\
\hline $\begin{array}{l}\text { Southern Federal } \\
\text { District }\end{array}$ & 46 & 4.8 & 46 & 5.0 & 43 & 5.2 & 43 & 5.2 \\
\hline $\begin{array}{l}\text { North Caucasian } \\
\text { Federal District }\end{array}$ & 50 & 5.2 & 43 & 4.7 & 28 & 3.4 & 26 & 3.2 \\
\hline $\begin{array}{l}\text { Volga Federal } \\
\text { District }\end{array}$ & 106 & 11.1 & 102 & 11.1 & 92 & 11.0 & 91 & 11.0 \\
\hline $\begin{array}{l}\text { Ural Federal } \\
\text { District }\end{array}$ & 44 & 4.6 & 42 & 4.6 & 35 & 4.2 & 34 & 4.1 \\
\hline $\begin{array}{l}\text { Siberian Federal } \\
\text { District }\end{array}$ & 53 & 5.5 & 51 & 5.5 & 44 & 5.3 & 41 & 5.0 \\
\hline $\begin{array}{l}\text { Far Eastern } \\
\text { Federal District }\end{array}$ & 23 & 2.4 & 22 & 2.4 & 22 & 2.6 & 22 & 2.7 \\
\hline $\begin{array}{l}\text { Crimean Federal } \\
\text { District }\end{array}$ & & & & & 2 & 0.2 & 2 & 0.2 \\
\hline $\begin{array}{l}\text { Russian } \\
\text { Federation }\end{array}$ & & 100.0 & & 100.0 & & 100.0 & & 100.0 \\
\hline
\end{tabular}

The volume of issuance of unsecured consumer loans and car loans will be significantly reduced. However, with proper government support, the mortgage market can show positive growth rates.

The decrease in the level of sufficiency of banks' own funds will continue.

As noted above, the heterogeneity of the economic space of Russia with highly differentiated living conditions of the population and production in different territories has a significant impact on the structure and efficiency of its banking sector. And this, in turn, has the opposite effect on the further development of the region's economy. 
Let's see how credit institutions are geographically located in the context of federal districts.

As follows from the data in Table 1, there is an extreme unevenness in the distribution of credit institutions across the regions of the country.

The majority of banks are registered in the European part of the country, and very few regional banks beyond the Urals. Over $88 \%$ of the country's banking assets are controlled by credit institutions in Moscow and the Moscow Region.

Against the background of the active development of regional banks in large cities, which, as a rule, are industrial, transport and shopping centers (where both incomes and savings of the population are higher), there is a decrease in regional banks. There are several reasons.

First, the regulator's requirement for the minimum amount of banks' capital. In terms of its consequences - the decision to increase the requirements for the minimum value of the authorized capital of commercial banks.

Based on the requirements of the Bank of Russia to the authorized capital, many banks are undergoing the following transformations:

unite for the purpose of increasing and preserving capital, i.e. there is a merger of capital; large banks buy smaller banks, takeover occurs;

are closed due to bankruptcy or in connection with the inability of small banks to comply with the requirements of the Central Bank for the work and the size of the authorized capital, i.e. there is a self-liquidation or liquidation by a court decision;

change their status, becoming a non-bank credit institution.

We have to admit that not only the so-called "laundering" banks, which do not affect the development of the system, are leaving the market, but also regional banks with an established client base and completely "market" business are disappearing.

In recent years, the Russian banking sector has entered a new period - a period of qualitative development: gradual consolidation of credit institutions, expansion, competition, expansion of the range of banking products provided, changes in the structure of assets and liabilities of credit institutions, strengthening of banks' specialization, and tightening of regulatory requirements. The increase in minimum capital requirements increases, on the one hand, the stability of the banking sector, and on the other hand, contributes to the crowding out and absorption of regional, small and medium-sized banks, which, due to the low volume of available funds, are not able to adequately develop risk management and innovative technologies.

Nowadays, small regional banks compete on equal terms with branches of federal-level banks in working with individuals. The share of deposits in the liabilities of regional banks is constantly growing.

The fact that the population actively chooses regional banks is not surprising - it is a matter of trust in their financial institutions. Regional banks have potentially very good market positions in this market segment. The level of trust in "their" banks allows them to work successfully in the mass market.

Regional banks have a number of significant advantages over branches (subsidiary banks) of other banks.

First, it is a stronger advertising presence in the region. The advertising budget of a large regional bank, as a rule, is larger than that of branches of federal (mainly Moscow) banks. The effect of the bank's presence is created by constant advertising. According to surveys, outdoor advertising and advertising on local TV channels have the greatest influence on medium and small clients (since there are several times more of them than federal ones). 
Secondly, a more flexible approach to the client. The client can communicate with highly empowered professionals. Even not being a large client, he can count on an individual approach. This is very important for small and medium-sized businesses.

Thirdly, the bank's great flexibility in the competition. A regional bank can devote more resources to studying the regional market, competitors, more quickly respond to the actions of competitors and customer requests (rates, tariffs). Branches, on the contrary, have limited opportunities and coordinate their actions with the parent bank in many areas. All these advantages are important when working in the market of medium and small clients, as well as in the market for individuals.

For large business, they almost do not matter, since work with a large client is carried out individually.

The problem of the development of regional banks is more of an administrative and political issue. An example is the following fact. According to the ARB, recently, many banks located in the regions have lost their largest clients.

The regional administrations, seeing the approach of the Government of the country to support only systemically important banks, recommended that the most important local enterprises be served in the largest banks [9-12].

The economic health of a region depends on how strong its banking sector is. The future of the regional economy will depend on the banking sector.

Regional banks have advantages when operating in the medium and small client market, as well as in the retail market.

This market segment is interesting not only because small businesses have begun to develop dynamically and are not divided among large banks, but also because the state is interested in its development.

As the practice of recent years shows, in comparison with the segment of large corporate loans, lending to small and medium-sized enterprises in the Russian Federation has demonstrated greater resistance to crisis impacts. Although, in the face of the rise in the cost of their own resource base, the deterioration of the financial situation of borrowers, commercial banks were forced to switch to a conservative credit policy expressed in tightening both the price and non-price conditions of their financing.

\section{Conclusions}

Credit institutions are ready to actively increase volumes in this direction, but, in view of the growth of credit risks, only with the support of the Government.

- At the same time, the crisis in the economy and the presence of constraining factors in lending (high key rate) did not seriously affect the alignment of forces in the SME lending market.

- The country's banking system has been tasked with not only quantitative, but also qualitative development of the Russian banking system.

- For this, in our opinion, systematic work should be continued in the following areas:

- development of interest rate policy;

- more differentiated regulation of the work of credit institutions;

- $\quad$ ensuring fair access of all banks to resources;

- $\quad$ support of stable operating small commercial banks. 


\section{References}

1. Bank ratings: http://www.banki.ru/banks/ratings/

2. L.V. Pushkareva, O.A. Galochkina, O.L. Bezgacheva, Current trends in the banking system of Russia, Espacios 40 (4), 22-29 (2019)

3. Tough on regional banks: http://arb.ru/b2b/news/k_regionalnym_bankam_proyavili_zhestkost-9924033/

4. Expert rating agency: www.raexpert.ru/researches/factoring/factoring_1q_2015

5. Medvedev approved a list of eight banks for additional capitalization for 527.4 billion rub.:http://arb.ru/b2b/news/medvedev utverdil_spisok_iz_vosmi_bankov dlya dokapi talizatsii na $527 \quad 4$ mlrd_rub-9915620/

6. www.asv.org.ru/for_banks/capitalization/002.pdf.

7. Instruction of the Central Bank of the Russian Federation of 02.04.2010 No. 135-I "On the procedure for the Bank of Russia to make a decision on state registration of credit institutions and the issuance of licenses for banking operations").

8. Anti-crisis tactics and strategy: interaction between banks and regulators: ARB 2015 Annual Report (Prepared for the 26th Congress of the Association of Russian Banks): http://arb.ru/upload/files/siezd/ARB-XXVI-Doklad.pdf.

9. http://arb.ru/b2b/news/k_regionalnym_bankam_proyavili_zhestkost-9924033/

10. Order of the Government of the Russian Federation of January 27, 2015 N 98-r "On approval of the plan of priority measures to ensure sustainable economic development and social stability in 2015”: www.consultant.ru/document/cons_doc_LAW_174635/

11. The list of banks for the implementation of measures to increase their capitalization by the State Corporation "Deposit Insurance Agency".

12. S.A. Chunikhin, E.A. Kuzmin, L.V. Pushkareva, Studying the banking industry's stability through market concentration indices, Entrepreneurship and Sustainability Issues 6(4), 1663-1679 (2019) 